\title{
School of Management
} UNIVERSITY OF MINNESOTA

MARKETING ENERGY CONSERVATION TO HOMEOWNERS:

AN ACTION PROGRAM FROM PUBLIC POLICY RESEARCH

by

William Rudelius, Gary Dodge, and Richard Weijo

Working Paper No. 65A

\section{Working Paper}

CURA has supported the work of the author(s) of this report but has not reviewed it for final publication. its content is solely the responsibility of the author(s) and is not necessarily endorsed by CURA.

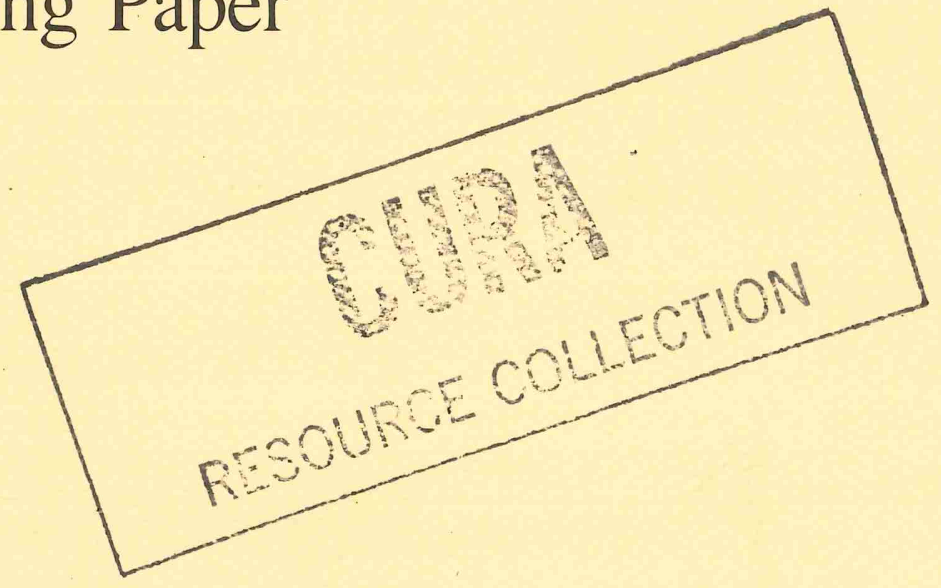




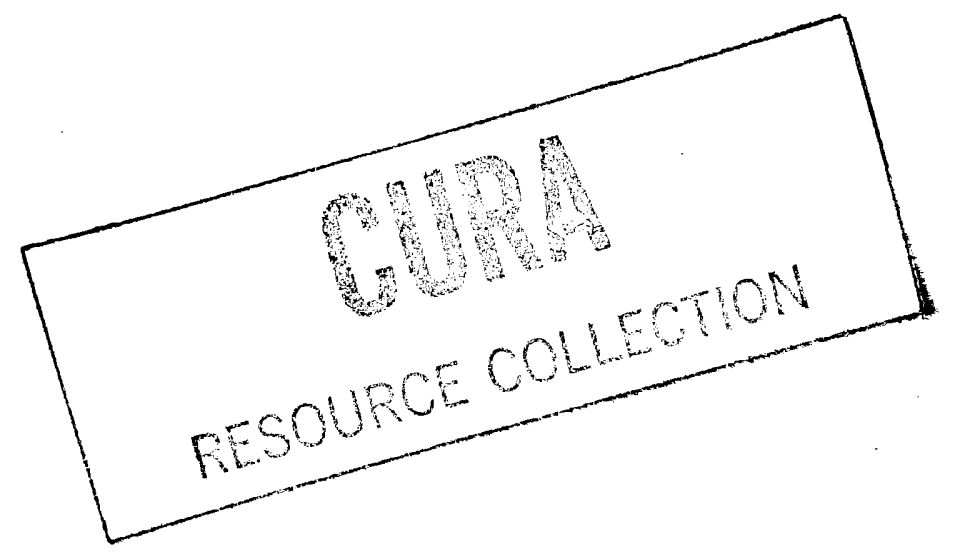

MARKETING ENERGY CONSERVATION TO HOMEOWNERS: AN ACTION PROGRAM FROM PUBLIC POLICY RESEARCH

by

William Rudelius, Gary Dodge, and Richard Weijo

Working Paper No. 65A

School of Management University of Minnesota

27119 th Avenue South

Minneapolis, MN 55455

August , 1982

Funds for the research were provided by the School of Management and Center for Urban and Regional Affairs of the University of Minneosta and the Energy Office of the City of Saint Paul. 
Marketing Energy Conservation to Homeowners:

An Action Program from Public Policy Research

\begin{abstract}
Appeals for energy conservation directed at homeowners that stress partriotism and social responsibility have not worked. The authors believe that providing a homeowner with more precise information that will show specific dollar costs and savings for various energy actions will stimulate meaningful trade-offs that benefit the individual homeowner. They further believe that broadly-conceived, publicly-sponsored marketing strategies can assist individual consumers make more informed energy-conservation choices from among the continuous, seasonal, and one-time actions available to them. And having public policymakers focus efforts on the most cost-effective, energy-saving actions for households, in turn, will give the greatest community-wide energy savings for a fixed amount of public expenditures.
\end{abstract}


"SAVE ENERGY: REDUCE AMERICA'S DEPENDENCE ON FOREIGN OIL!" This type of. appeal we see or hear almost daily in newspapers and on television to inspire us to save energy -- at home, in our cars, at work. There is only one problem with appeals to patriotism and social responsibility: they don't work.

\section{Energy, Consumers, and Public Policy}

Consumers and the Tragedy of the Commons

The reason that these appeals don't work, which causes chaos for public policy, is that energy is an example of the classic "tragedy of the commons": a pasture open to all of a town's herders at no cost ultimately produces overgrazing and useless grazing land. This is because each herder -- in pursuing his own best interest -- grazes more and more of his animals on the pasture until the land is worthless for grazing by all (Hardin 1968). This conflict between individual and collective well-being and short and long-term good also applies to the use of energy. The individual increases his energy use without concern for the fixed supply of energy and the collective long-term good that requires conservation (Stern 1976; Johnston, Cooper, and Page 1981).

So what will work to save energy?

Individuals will take actions to save energy for one main reason: it is in their own best short-run and long-run interests to do so (Hirst and Lazare 1980). To the typical consumer these benefits usually boil down to money savings, a message used more by public policymakers in Canada than the United States and with success (Allen, Callantone, and Schewe 1982). Unfortunately, consumers generally do not know what actions to take to save energy, the size of the potential benefits, and the time and costs involved (Farhar et al 1979; Richman 
1979; Booz-Allen \& Hamilton 1980). For consumers to take energy-saving actions around the home, they need more precise information on the dollar costs and dollar savings (benefits) of such actions (Verhallen and Van Raaij 1981) and an increased awareness of the price increases in energy (Heslop, Moran, and Cousineau 1981). This will enable communities to encourage households to save energy by stressing actions that will be likely to save them the most energy for a given expenditure of funds by governments and energy utilities. So the tragedy-of-the-commons dilemma here can be addressed by giving more precise information on energy-saving opportunities to the specific household segments that need it while also using available public policy incentives.

Task for Public Policy

The federal government wants to encourage energy conservation among households for a number of desirable reasons: reducing oil-related deficits in the U.S. balance of trade, controlling inflation, and avoiding dependence on foreign energy sources in event of war. At the same time consumers want to reduce their energy costs to save money for other uses in maintaining their life style -- necessities, luxuries, or savings. The federal government is also concerned with the income redistribution resulting from past and future deregulation of oil and natural gas prices; these especially impact low-income households that often spend about 21 percent of their income on energy compared to 4 percent for middle-income households.

The goal of public policymakers is clear: take actions that facilitate the greatest household energy savings by consumers that, in turn, will save the most energy for the nation (Evans, Ritchie, and McDougall 1978/79; McDougall and Ritchie 1979). The prescription is straightfoward: (1) identify potential energy saving activities by a household, (2) determine the dollar costs and 
benefits to a household for each activity, (3) communicate these dollar costs and benefits as clearly as possible so each household can make energy use tradeoffs that are in its own best interest, and (4) facilitate actions by those households unable to be motivated by information alone (such as low-interest rate financing to aid low-income households). But it is in implementing this prescription that public policy encounters problems, at least partly because of the mismatch between conservation initiatives taken by policymakers and relevant studies by researchers (McDouga11, Claxton, Ritchie, and Anderson 1981).

\section{objectives and Approach}

\section{Objectives of Research}

Our focus is on residential energy conservation by owners of existing homes. We have three main research objectives: (1) to provide a simple integrative framework to describe the decisions homeowners make in saving energy around their homes, (2) to relate programs of governments and energy utilities and existing research studies to this framework, and (3) to use energy-saving actions and plans of a large sample of households to estimate potential community-wide energy savings available by homeowner segments. We will then use our integrative framework to recommend actions by local governments and energy utilities and suggest future research to give focus to energy-conservation programs.

\section{Approach}

Three main sources of data were used in the study: published reports, survey data on energy-conservation activities by homeowners, and estimates of dollar costs and savings of these activities provided by government agencies and energy utilities. 
Published reports by various government agencies in the United States and Canada outlined energy-conservation programs that have been undertaken or are planned. Studies by private or university researchers and energy utilities also provided detailed information.

On February 13-15, 1980, Saint Paul closed city offices for three days so 3,000 city workers and volunteers could collect information from 34,000 city households and businesses on their energy-conservation activities. The selfadministered questionnaire identified 18 common energy-conservation activities households could take. For each activity the respondent was asked to indicate if he or she had performed the energy activity and if not, why not. The survey also collected information on age, income, and size of home the owner or renter lived in. A stratified random sample of 3,000 respondents was selected to weight homeowners, renters, and neighborhoods in proportion to their true population size in Saint Paul. Because encouraging energy-saving actions by renters is outside the scope of this study, our analysis is based on the 58 percent of the sample of 3,000 Saint Paul households that are homeowners.

Physical characteristics of a home exert special influence on its energy use (Ritchie, McDouga11, Claxton 1981). Our study focused on three such characteristics: number of floors, number of bedrooms, and age of home. An analysis of Saint Paul homes showed three configurations of homes that were representative of homes in the city: a 1-floor, 2-bedroom home built between 1946 and 1965; and a 2-floor, 3-bedroom home built between 1946 and 1965; and a 3-floor, 4-bedroom home built before 1945. The local energy utility and city and state energy agencies provided us with estimates of dollar costs and savings for each of the 18 energy activities for each of these three configurations of homes, assuming typical winter weather and temperatures. 
Integrative Framework

Decisions by households on which energy-saving actions to take always involve time expenditures in acquiring information and possible self-help training, and they often require cost commitments as well. They are sufficiently -complex that they typically involve a sequence of specific steps to be taken by households. The top half of Figure 1 shows a four-stage sequence that describes the stages a household goes through in making a conscious energy-saving decision: (1) awareness, (2) choice, (3) implementation, and (4) use and evaluation. This sequence applies both to energy-saving decisions for new homes, which are outside the scope of our study, as well as to "energy retrofits" for existing homes. It also is useful for analyzing both high-cost decisions (installing a new furnace or additional wall insulation) and low-cost ones (installing weatherstripping or caulking). Weijo and Hartley (1981) have validated these four stages in a homeowner's decision to conserve energy using a unidimensional unfolding model.

This four-stage sequence has four other key advantages. First, it reflects the current structure of energy-conservation programs of governments and energy utilities. Second, it provides a framework to use in integrating published research studies and actual programs of governments and energy utilities -- two important streams of activity that bear little relationship to each other. Third, it permits energy-saving actions targeted at specific homeowner segments to be tied to estimates of potential community-wide energy savings, estimates that are critical in public-policy decisions. Finally, it enables the the barriers that tend to impede household energy decisions to be addressed in each of the four stages. These barriers, which are adapted from Deutscher and Munro (1980), appear in the bottom half of Figure 1. 


\section{Stages and Description of a Homeowner's \\ Decision \\ Process:}

\section{Stage 1: Awareness Stage 2: Choice Aware of an Energy Problew Around the Howe

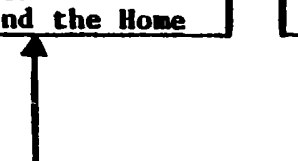 \\ Homeowner May Change Future Energy-Conserving Practices \\ Stage 3: Implementation r Identities icernative Solution and Makes a Cholce Implement the Chosen Alternative to Try to Solve Energy Problen \\ Stage 4: Use \&valuat ton Homeowner $\mathrm{U}_{\mathrm{ges}}$ the \\ Chosen Alternative and \\ Evaluates its Effective- Iness \\ Depending on Evaluations of Effectiveness of the Act lon}

\section{Potent1al}

Barriers for Homeowner at Each Stage of the Decision Process
Lack of Information to Deternine Whether a Problew Exists that the Honeowner Can Solve
Inab111ty to Deterine and Undergtand the Benefits and Costs of Alternative Energy-Saving Acticns
Inabillty to Undertake Action Himelf/Herself: to F1nd Satiefact ory

Contractor or Suppliers to PInance the Action
Difficulty in Evaluating the Savings Provided By Completed Energy ConservIng Actions

Figure 1: Stages a Homeowner Goes Through in Taking an Energy-Conserving Action - and Potential Barriers to that Action 
Programs and Research on Household Energy Conservation

An extensive study by the Energy Project at the Harvard Business School (Stobaugh and Yergin 1979) concludes that conservation is the only way to balance energy sources and needs in the U.S. during the coming decade. And because about 20 percent of energy used in the United States is around the home, household energy conservation represents an important potential for achieving significant savings. Conservation here includes using energy more efficiently and changing household behaviors to avoid high or excessive use, such as reducing indoor winter temperatures to $68 \mathrm{~F}$.

Household energy use in a city the size of Saint Paul is staggering. The residences housing its 280,000 people currently consume the equivalent of $22 / 3$ million barrels of oil annually for its electric, natural gas, and fuel oil needs. This averages 24 barrels of oil per household, about three-fourths of it for space heating and cooling.

In 1978 the average bill for a Saint Paul home for heating and cooling was $\$ 800$. In early 1980, the same homeowner was paying more than $\$ 1,200$ for heating and cooling -- an increase of more than 50 percent in less than two years. Over half of Saint Paul's housing units are more than 50 years old and contain little or no insulation; many are not properly weatherized for winter. In a typical unweatherized home, numerous small leaks and cracks can give an energy loss equal to that of an open window. This illustrates the potential for energy savings present in existing housing units in the United States.

Programs to Stimulate Household Energy Conservation

Agencies of federal, state, and local governments and energy, utilities have directed actions at each of the four stages in a household's decision to conserve 
energy in an attempt to overcome the barriers to action cited in Figure 1 (Department of Energy 1979a; 1979b). Examples of actions by each of the three levels of government and by energy utilities in the United States and Canada are summarized in Table 1 .

Among the dozens of studies undertaken on various aspects of energy conservation (Farhar et al 1979, Anderson and McDougall 1980), few are formal experiments or systematic evaluations involving actual programs shown in Table 1 . One key exception is the program of the Residential Conservation Service (RCS) of the U.S. Department of Energy that requires electric and natural gas utilites to offer in-home energy audits to consumers to help them save energy. The services offered by utilities under the RCS program include practical actions directed at all four stages of a household's decision process.

Evaluation of the RCS audits reveals that often less than five percent of those contacted request an in-home audit. Also, requests for do-it-yourself audits are nearly four times those for in-home audits, and a majority of audited participants take conservation actions that are most likely to be quick-payback actions that can be done without a contractor's assistance and do not affect their life style in an important way (Berry et al 1981). This desire for a quick payback applies to homeowners in general, with lower income households wanting faster payback (Cunningham and Brondel 1978). Participants in the RCS audit program are also more likely to own a larger home, be more energy-conscious, and have higher income and education levels than nonparticipants (Walker and Coney 1981; Berry et al 1981).

Key conclusions from evaluations of the in-home RCS audit: people conserve energy to save money, are discouraged from energy conservation by high-cost 
TABLE 1

ACTIONS TAKEN BY FEDERAL, STATE, AND LOCAL GOVERNMENTS AND ENERGY UTILITIES TO PROMOTE ENERGY-SAVINGS ACTIONS BY HOMEOWNERS

\begin{tabular}{|c|c|c|c|c|}
\hline \multirow{2}{*}{$\begin{array}{l}\text { Organization } \\
\text { Taking Action }\end{array}$} & \multicolumn{4}{|c|}{$\begin{array}{c}\text { Stage of Homeowner's Decision to Conserve Energy to } \\
\text { Which Action is Directed }\end{array}$} \\
\hline & Alrareness & Choice & Implenent at ion & Use \& Evaluation \\
\hline $\begin{array}{l}\text { Federal } \\
\text { Govermient }\end{array}$ & $\begin{array}{l}\text { Provide publi- } \\
\text { cations, } \\
\text { films, work- } \\
\text { shope }(I, Z)\end{array}$ & $\begin{array}{l}\text { Set cost- } \\
\text { effective } \\
\text { energy otan- } \\
\text { dardo before } \\
\text { financing } \\
\text { projects } \\
\text { Publish re- } \\
\text { ports on } \\
\text { energy } \\
\text { efficient } \\
\text { technolo- } \\
\text { gies(I) }\end{array}$ & $\begin{array}{l}\text { Offer weatheriza- } \\
\text { tion progran for } \\
\text { the needy } \\
\text { Pinance energy- } \\
\text { saving activities } \\
\text { for neighborhood } \\
\text { cooperatives } \\
\text { Pinance and give } \\
\text { tax credit for } \\
\text { energy-saving } \\
\text { houe investments }\end{array}$ & $\begin{array}{l}\text { Provide consumer- } \\
\text { protection in- } \\
\text { formation on } \\
\text { energy-saving } \\
\text { ections(I) } \\
\end{array}$ \\
\hline $\begin{array}{l}\text { State } \\
\text { Governmeats }\end{array}$ & $\begin{array}{l}\text { Run public } \\
\text { service } \\
\text { announcements } \\
\text { on radio and } \\
\text { IV (I,P) } \\
\text { Publicize } \\
\text { residential } \\
\text { sudits and } \\
\text { workshopa(I) }\end{array}$ & $\begin{array}{l}\text { Publish resi- } \\
\text { dential guides } \\
\text { on energy con- } \\
\text { servation and } \\
\text { financial } \\
\text { assistance(I) } \\
\text { Provide library } \\
\text { and toll- } \\
\text { fres hotline } \\
\text { asoistance } \\
\text { (I) }\end{array}$ & $\begin{array}{l}\text { Develop master } \\
\text { lists of approved } \\
\text { lenders, suppliers, } \\
\text { and contractors } \\
\text { for hows, energy } \\
\text { audits(I) }\end{array}$ & $\begin{array}{l}\text { Hendle consumer } \\
\text { complaints } \\
\text { received by } \\
\text { homeovners for } \\
\text { energy actions } \\
\text { arranged by } \\
\text { public utilities } \\
\text { or appliers(I) }\end{array}$ \\
\hline $\begin{array}{l}\text { Locel } \\
\text { Governments }\end{array}$ & $\begin{array}{l}\text { Organize cou- } \\
\text { munity meet- } \\
\text { ings, displays } \\
\text { home shows, } \\
\text { exhibits, ard } \\
\text { fairs (I) } \\
\text { Provide speakers } \\
\text { outreach pro- } \\
\text { gran, and bill } \\
\text { stuffers(I,P) } \\
\text { Run an "energy } \\
\text { bus"(I) }\end{array}$ & $\begin{array}{l}\text { Provide energy } \\
\text { hotlines(I) } \\
\text { Develop stan- } \\
\text { dards for } \\
\text { insulation, } \\
\text { heat loss, } \\
\text { gas heating } \\
\text { hookups for } \\
\text { new custo- } \\
\text { mers(I) }\end{array}$ & $\begin{array}{l}\text { Provide free attic } \\
\text { and floor insula- } \\
\text { tion to the needy } \\
\text { Inotall power load } \\
\text { management devices } \\
\text { on vater heaters } \\
\text { and air condition- } \\
\text { ers(F) } \\
\text { Provide financing } \\
\text { property tax exemp- } \\
\text { tions for energy } \\
\text { saving actions }\end{array}$ & $\begin{array}{l}\text { Design inaulation } \\
\text { inapection form } \\
\text { and certificate }\end{array}$ \\
\hline $\begin{array}{l}\text { Energy } \\
\text { Utilities }\end{array}$ & $\begin{array}{l}\text { Announce the } \\
\text { availability of } \\
\text { home energy } \\
\text { auditg(I) } \\
\text { Use billboard } \\
\text { ads and bill } \\
\text { scuffers with } \\
\text { conserve energy } \\
\text { appeals(I,P) } \\
\text { Compare monthly } \\
\text { energy bill } \\
\text { with that for } \\
\text { same wonth } \\
\text { che previous } \\
\text { year( }(F)\end{array}$ & $\begin{array}{l}\text { Perform home } \\
\text { energy audits } \\
\text { and make } \\
\text { recomaende- } \\
\text { tions(I) }\end{array}$ & $\begin{array}{l}\text { Assist in installa- } \\
\text { tion and financing } \\
\text { of energy-saving } \\
\text { activities } \\
\text { Frovide lists of } \\
\text { approved contrac- } \\
\text { tors, lenders, and } \\
\text { and suppliers( I) } \\
\text { Allow payment with } \\
\text { utility bills }\end{array}$ & $\begin{array}{l}\text { Conduct post- } \\
\text { installation } \\
\text { inspections(I) } \\
\text { Organize office } \\
\text { consumer ser- } \\
\text { vices to handle } \\
\text { consumer com- } \\
\text { plaints(I) }\end{array}$ \\
\hline
\end{tabular}

The letter in parentheses following some of the actions refer to the four types of factors described by Stern and Gardner (1981) often used to stimulate energy conservation by consumers: information ( $I)$, prompts ( $P$ ), monetary incentives $(M)$, and feedback $(F)$. Actions not having a letter do not fit conveniently into the stern and Gardner structure. 
measures, don't want to make lifestyle changes, and don't understand which conservation measures are most effective (Booz-Allen and Hamilton 1980). The appeals that are seen as most effective by consumers are saving money through conservation and do not involve stressing lifestyle changes, sacrifice, and the national interest (Booz-Allen and Hamilton 1980).

Behavioral Research on Households

Stern and Gardner (1981) note that behavioral research on households has identified four types of independent variables intended to stimulate energy conservation: (1) information on ways to conserve energy, (2) prompts (exhortations to energy-saving actions), (3) monetary incentives (direct payments for reduction in energy use), and (4) feedback (information on current rates of consumption). Table 1 shows that in actual practice information is clearly the most widely used by governments and energy utilities, followed by prompts. Also, information is widely used at all four stages of household decision making. The cost of using feedback means it has rarely been used in actual practice and monetary incentives, never. Those financial incentives that are shown in Table 1 are facilitators of planned actions (free attic insulation to the needy and tax credits for energy-saving home investments) rather than reward payments for past energy savings. They have an information component of the stimulus to action as well as a financial one.

Importance and Nature of Energy Information

For budget reasons alone it appears that practical public policy actions in the future -- as in the past -- must stress some form of information provided to homeowners. Public service commissions and energy utilities appear to be equally credible sources of this information (Craig and McCann 1978a). But research 
on the effectiveness of such information gives mixed results. Some suggests it may be effective in reducing household energy use only when combined with public commendation (Hayes and Cone 1977; Kohlenberg, Phillips, and Proctor 1976; Winett et al 1978; Milstein 1977), and feedback and goal setting (Becker 1978). But another study found that properly designed information alone can affect a household's energy consumption (Craig and McCann 1978b). Gaskell, E11is, and Pike (1980) found that while information plus feedback led to the greatest reduction in household fuel consumption, information alone was also effective. And, information plus a free shower-flow restrictor caused New England residents to take low-cost and no-cost energy conservation actions (Hutton and McNeill 1981b)。

Russo (1977) notes that in energy decisions the increase or decrease in the benefit of an action is relatively clear (the discomfort of a lowered thermostat), but the dollar cost is known very imprecisely. Hanna (1978) argues for standardizing the way financial returns from energy-saving investments -like payback and rate of return -- are described to facilitate informed consumer choice. The sheer magnitude of the information needed by consumers presents special communications problems (Bloom and Novelli 1981) that necessitate going beyond the traditional communication channels from advertising (Rothchild 1979). Because of important regional differences in energy use, local governments or energy utilities may be an especially effective means of facilitating energy savings (Frieden 1981; Cannon 1980). It is important for them to tailor-make information to consumers in an understandable format (Beales et al 1981), perhaps through such channels as hardware stores, neighborhood groups, do-it-yourself outlets, contractors, or community-action groups (Geller 1982) that have unique access to specific consumer segments. 
Results and Discussion

Types of Energy-Conservation Activities

Energy conservation activities around the home form a rough continuum that relate to how often action must be taken to acheive energy savings: continuous (requiring daily attention), seasonal (performed once or twice a year), and onetime (generally done once in the life of a home).

The 18 energy-saving activities included in the Saint Paul survey divide into the continuous, seasonal, and one-time classes as shown in the left-hand column of Table 2. While an activity might fall in a different category, depending on the household, the three classes generally separate distinctly. different kinds of energy-saving activities.

Plans and Actions by Homeowner Segments

If survey respondents indicated they were not taking an energy-saving activity, they were asked to identify the reason. Each reason was allotted to one of the three stages in a household's decision to conserve energy that precede the final stage of use and evaluation, such as:

Awareness stage - Activity won't save energy; I'm not sure about the activity.

Choice stage - I don't know how to do the activity.

Implementation stage - I don't have enough money; I'm physically unable to do it.

The final stage (use and evaluation) includes those respondents reporting they had done or were continuing to do the activity.

Table 2 summarizes the survey results for each of the 18 energy-saving activities, broken down by household decision stages. Three-quarters or more of 
TABLE 2

PERCENTAGE OF HOMEOWNERS AT EACH STAGE

OF A DECISION TO PERFORM AN ENERGY-SAVING ACTIVITY

\begin{tabular}{|c|c|c|c|c|c|c|}
\hline \multicolumn{2}{|r|}{ Energy Conservation Activity } & \multicolumn{4}{|c|}{ Stage of Household's Decision to Conserve Energy } & \multirow{2}{*}{$\begin{array}{l}\text { Households } \\
\text { Responding } \\
\text { Does Not } \\
\text { Apply }\end{array}$} \\
\hline $\begin{array}{l}\text { Gen'1 } \\
\text { Class }\end{array}$ & Specific Activity & Awarenes 8 & Choice & Iluplement at ion & Use \& Evaluation & \\
\hline \multirow{2}{*}{$\begin{array}{l}\text { Con- } \\
\text { tin- } \\
\text { uous }\end{array}$} & $\begin{array}{l}\text { Regularly turn off unused lights } \\
\text { Close drapes and shades at night }\end{array}$ & $\begin{array}{l}1 \% \\
3\end{array}$ & $\begin{array}{l}1 \% \\
1\end{array}$ & $\begin{array}{l}0 \% \\
0\end{array}$ & $\begin{array}{l}98 \% \\
93\end{array}$ & $\begin{array}{l}0 \% \\
3\end{array}$ \\
\hline & $\begin{array}{l}\text { Close off rooms } \\
\text { Turn down furnace thermostat }\end{array}$ & $\begin{array}{r}10 \\
4\end{array}$ & $\begin{array}{l}2 \\
1\end{array}$ & $\begin{array}{l}0 \\
1\end{array}$ & $\begin{array}{l}61 \\
92\end{array}$ & $\begin{array}{r}27 \\
2\end{array}$ \\
\hline \multirow{2}{*}{$\begin{array}{l}\text { Sea- } \\
\text { sonal }\end{array}$} & $\begin{array}{l}\text { Caulk cracks } \\
\text { Weatherstrip doors and windows }\end{array}$ & $\begin{array}{l}4 \\
3\end{array}$ & $\begin{array}{l}16 \\
16\end{array}$ & $\begin{array}{l}2 \\
3\end{array}$ & $\begin{array}{l}75 \\
77\end{array}$ & $\begin{array}{l}3 \\
1\end{array}$ \\
\hline & $\begin{array}{l}\text { Replace broken windows and } \\
\text { storm doors } \\
\text { clean and tune up the furnace }\end{array}$ & $\begin{array}{l}1 \\
4\end{array}$ & $\begin{array}{r}8 \\
13\end{array}$ & $\begin{array}{l}2 \\
4\end{array}$ & $\begin{array}{l}82 \\
76\end{array}$ & 7 \\
\hline \multirow{5}{*}{$\begin{array}{l}\text { One- } \\
\text { time }\end{array}$} & $\begin{array}{l}\text { Install clock thermostat } \\
\text { Install more efficient furnace }\end{array}$ & $\begin{array}{l}37 \\
16\end{array}$ & $\begin{array}{r}17 \\
7\end{array}$ & $\begin{array}{l}14 \\
20\end{array}$ & $\begin{array}{l}11 \\
29\end{array}$ & $\begin{array}{l}21 \\
28\end{array}$ \\
\hline & $\begin{array}{l}\text { Turn down water heater thermostat } \\
\text { Install shower flow restrictor }\end{array}$ & $\begin{array}{l}13 \\
38\end{array}$ & $\begin{array}{r}4 \\
17\end{array}$ & $\begin{array}{l}1 \\
7\end{array}$ & $\begin{array}{l}76 \\
14\end{array}$ & $\begin{array}{r}6 \\
24\end{array}$ \\
\hline & $\begin{array}{l}\text { Insulate hot water pipes } \\
\text { Insulate hot water heater }\end{array}$ & $\begin{array}{l}32 \\
32\end{array}$ & $\begin{array}{l}23 \\
22\end{array}$ & $\begin{array}{l}8 \\
8\end{array}$ & $\begin{array}{r}-23 \\
26\end{array}$ & $\begin{array}{l}14 \\
12\end{array}$ \\
\hline & $\begin{array}{l}\text { Insulate the attic } \\
\text { Insulate the crawl space }\end{array}$ & $\begin{array}{l}7 \\
8\end{array}$ & $\begin{array}{r}13 \\
9\end{array}$ & $\begin{array}{l}8 \\
7\end{array}$ & $\begin{array}{l}66 \\
41\end{array}$ & $\begin{array}{r}6 \\
35\end{array}$ \\
\hline & $\begin{array}{l}\text { Insulate the walls } \\
\text { Install fireplace doors/caps }\end{array}$ & $\begin{array}{r}16 \\
8\end{array}$ & $\begin{array}{l}8 \\
8\end{array}$ & $\begin{array}{r}18 \\
6\end{array}$ & $\begin{array}{l}50 \\
19\end{array}$ & $\begin{array}{r}8 \\
59\end{array}$ \\
\hline
\end{tabular}


the respondents report they have done or are doing all of the continuous and seasonal activities except for closing off rooms' (reported by 61 percent). Over 65 percent report doing two of the one-time activities (turning down the waterheater thermostat and insulating the attic). Less than one-quarter report undertaking relatively innovative energy-saving activities like installing clock thermostats, water flow restrictors, and fireplace doors or chimney caps. Only about one-quarter to one-half report installing a more efficient furnace or insulating their hot water heater, hot water pipes, crawl space, or walls.

Table 2 also provides insights as to why households have failed to undertake specific energy-conservation activities. Lack of awareness is the reason over one-third of the respondents give for not having installed relatively innovative energy-saving devices like clock thermostats and water-flow restrictors. Problems of choice (for example, planning to do the activity or not knowing how) are the hurdles for about 8 to 16 percent of the households for the seasonal activities. The choice stage seems an important barrier for installing clock thermostats ( 17 percent), shower flow restrictors (17 percent), and insulation on hot water pipes (23 percent) and heaters (23 percent). Finally, implementation problems (lack of money or the physical ability) are the reasons about 18 to 20 percent of the respondents give for not installing a new furnace or wall insulation. Identifying at what stage households are in their decision process can suggest what the impediments are and possible ways to motivate consumers to action.

The percentage of respondents reporting that they have taken the energysaving activity varies by demographic characteristics. For all 18 activities a larger percentage of heads of households over 60 years of age report taking the activity than those younger. Similarly, households with annual incomes under $\$ 10,000$ report a higher percentage for all of the activities than those with 
higher incomes. Cunningham and Lopreato (1977) also found that a larger percentage of lower-income than higher income households reported taking energy actions. In contrast, Hutton and McNeil (1981a) found that households having less than $\$ 10,000$ in annual income and over 60 took the lowest percentage of conservation measures for these income and age groups. And research suggests that higher income households are more willing to spend money on energy-saving actions than lower income ones (Frieden 1981).

\section{Aggregate Potential Energy Savings}

At our request, the local public utility estimated the dollar costs of each energy-saving activity along with the resulting annual dollar savings for the three typical Saint Paul homes identified earlier, assuming they were average in energy use and physical condition. By weighting these estimates for each energysaving activity by the approximate proportion of each home in the city, it is possible to estimate the energy savings in 1980 dollars achieved on the survey for each activity and also the potential that exists for future savings.

Figure 2 shows this information for the three types of homes, broken down . into continuous, seasonal, and one-time actions. In interpreting Figure 2 , note that the horizontal scale, the stages of household decision making, is reversed. The left end of the scale shows activities already completed (the use and evaluation stage). These are estimates of the dollars of annual energy savings achieved through activities completed at the time of the survey. As one moves to the right in Figure 2, it is harder to achieve that amount of energy savings from city households because some households have more stages to complete.

Figure 2 suggests important public policy guidelines. It shows that activities completed at the time of the survey were conserving about $\$ 20$ million 

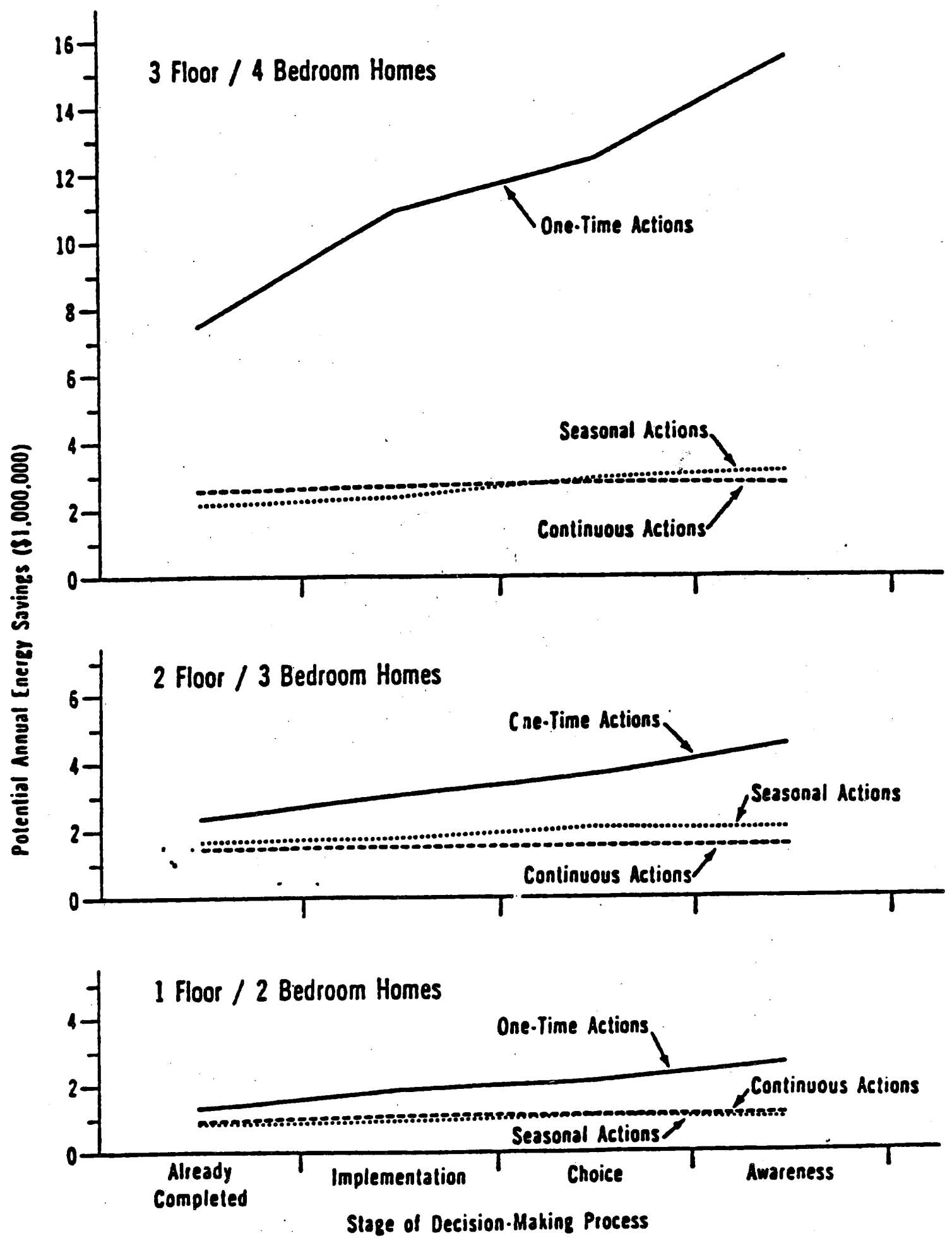

Figure 2. Potential annual energy savings in Saint Paul, by type of home, in 1980 dollars. 
in energy annually, about half of it in one-time activities. About two-thirds of these one-time energy-saving actions occurred in the older, large 3-floor, 4bedroom homes. Remaining savings were about evenly divided between continuous and seasonal activities similar figures have been developed for other market segments of age and income (Rudelius and Weijo 1980).

Actions and Their Effects on Costs and Life Style

Using the kind of information shown in Figure 2, public policy makers should focus their efforts and limited budgets on those household actions that will give the greatest incremental energy savings for available public funds invested in encouraging household conservation. But each household in tragedy-of-the-commons fashion is pursuing its own best interest -- trying to gain the maximum benefits from its energy expenditures at minimum cost and change to its life style. So public policy must recognize the important differences in cost to the homeowners and impact on life style when designing energy conservation programs. Figure 3 shows potential savings available when the 18 energy-saving actions are divided into two groups based on cost of the action (less than $\$ 25$ for a moderately handy do-it-yourself person or $\$ 25$ or more) for Saint Paul homeowners living in 2floor, 3-bedroom homes.

Figure 3 shows that as one moves from continuous to seasonal to onetime actions, the cost of the action to a homeowner increases. All of the continuous actions are no cost (turning off lights), the seasonal ones tend to be low cost (caulking cracks), and the one-time actions are often high cost (insulating walls or attic). According to Figure 3, homeowners report taking many of the no cost and low cost actions so that future energy savings are most likely to be won by having homeowners invest in higher-cost one-time actions while continuing to perform the continuous and seasonal actions. 
Savings from energy aetions costing a moderately-handy homeowner from SO(no cost) up to $\$ 24$ (low cost)

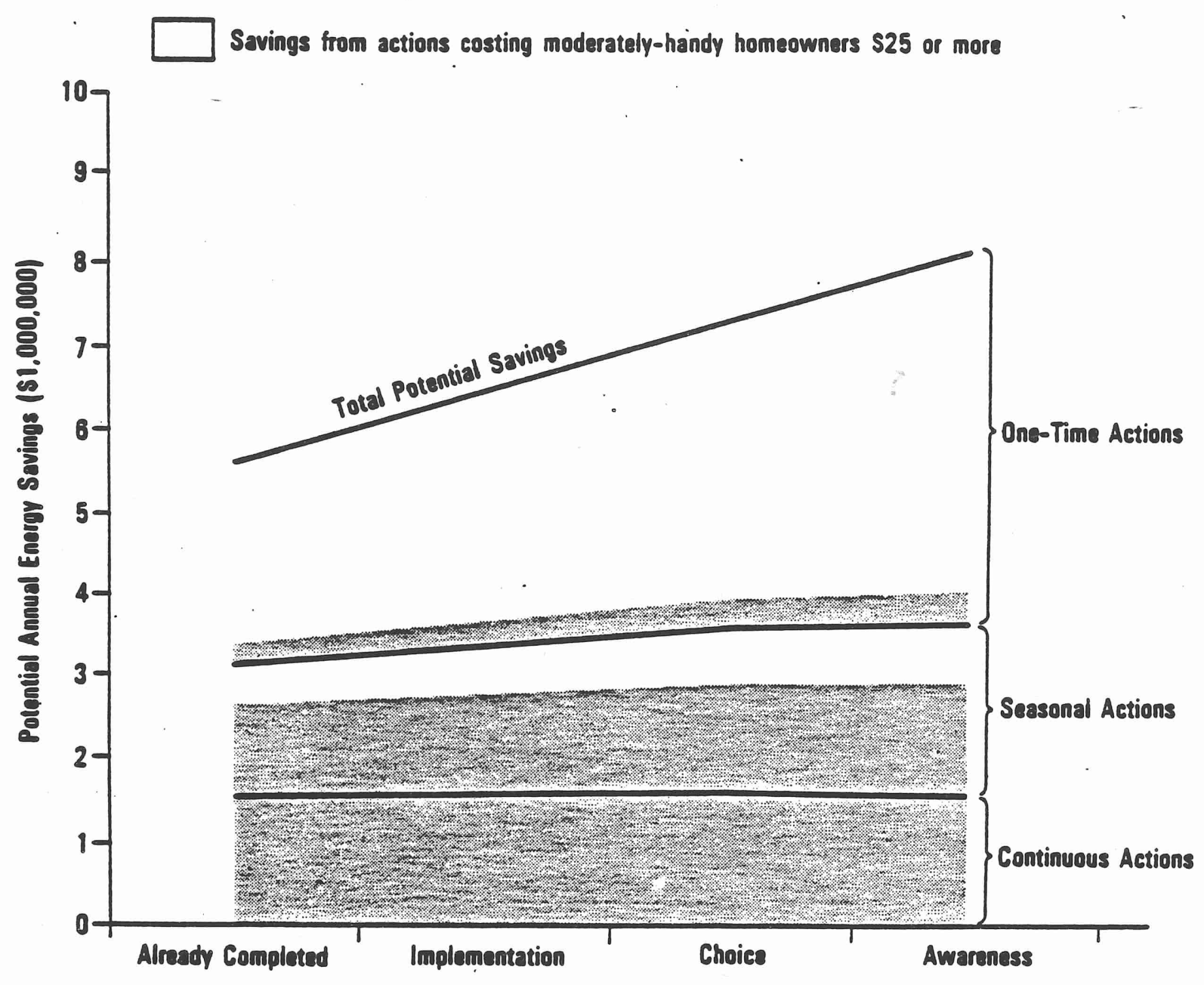

Figure 3. Potential annual energy savings in a 2 floor/3 bedroom Saint Paul home, in 1980 dollars, by cost of action to a moderately-handy homeowner. 
Information Format to Aid Consumer Trade-Offs

So far we have not quantified the benefits to an individual homeowner of taking an energy-saving action. One possible information format to help homeowners do this, based on cost data provided by the local energy utility, is shown in Table 3 for a typical 2-floor, 3-bedroom home in Saint Paul. The table provides estimates of costs, savings, and payback period for a homeowner who is either a do-it-yourselfer or would contract for improvements. Comparable information can be developed for a representative group of homes in any geographic region. The data do not reflect all pertinent household data that influence energy consumption such as number and ages of people living in the home, the number and size of doors and windows, or the way the fireplace is used. Still, the information permits meaningful trade-offs in terms of cost and lifestyle. For example, a one-time action of turning down the water-heater thermostat achieves about the same savings as the continuing action of repeatedly closing the drapes and shades at night. Yet they have dramatically different effects on daily life style.

The information in Table 3 gives further direction for public policy. For example, all continuous and seasonal actions have paybacks of one year or less for the do-it-yourself homeowner, indicating that potential savings shown in Figure 3 are achievable for these current consumers wanting minimal-cost actions with quick payback. Only four of the one-time actions shown in Table 3 have paybacks of less than 1.3 years, showing the need to educate consumers in order to gain the potential energy savings shown in Figure 3 . Since different homeowner segments (in terms of age, income, and size of homes) need to take 
TABLE 3

NET FIVE-YEaR doLLAR SAVINGS AND PAYbaCk PERIOd OF VARIOUS EAJERGY-SAVING ACTIONS

FOR A 2-FLOOR, 3-BEDROOM SAIMT PAUL HOME, II 1980 dOLLARS

\begin{tabular}{|c|c|c|c|c|c|c|c|c|}
\hline \multirow[b]{2}{*}{$\begin{array}{l}\text { General } \\
\text { Category }\end{array}$} & \multirow[b]{2}{*}{ Specific Action } & \multirow[b]{2}{*}{$\begin{array}{l}\text { F1rst-Year } \\
\text { Savings } \\
\text { (\$) }\end{array}$} & \multirow[b]{2}{*}{$\begin{array}{l}\text { Cost of } \\
\text { Materials } \\
(\$)\end{array}$} & \multirow[b]{2}{*}{$\begin{array}{l}\text { Cost of } \\
\text { Labor } \\
(\$)\end{array}$} & \multicolumn{2}{|c|}{ Net 5-Year Savings ${ }^{a}$} & \multicolumn{2}{|c|}{ Payback Period ${ }^{b}$} \\
\hline & & & & & $\begin{array}{c}\text { Do-It- } \\
\text { Yourse1f } \\
(\$)\end{array}$ & $\begin{array}{l}\text { Contracted } \\
\text { Out } \\
\text { (\$) }\end{array}$ & $\begin{array}{l}\text { Do-It } \\
\text { Yourself } \\
\text { (Years) }\end{array}$ & $\begin{array}{c}\text { Contracted } \\
\text { Out } \\
\text { (Years) }\end{array}$ \\
\hline $\begin{array}{l}\text { Contin- } \\
\text { uous }\end{array}$ & $\begin{array}{l}\text { Regularly turn off unused lights } \\
\text { Close drapes and shades at night } \\
\text { Close off rooms } \\
\text { Turn down furnace thermostat } \\
\end{array}$ & $\begin{array}{l}\$ 8 \\
\$ 7 \\
\$ 17 \\
\$ 44 \\
\end{array}$ & $\begin{array}{ll}\$ & 0 \\
\$ & 0 \\
\$ & 0 \\
\$ & 0 \\
\end{array}$ & $\begin{array}{ll}\$ & 0 \\
\$ & 0 \\
\$ & 0 \\
\$ & 0 \\
\end{array}$ & $\begin{array}{l}\$ 56 \\
\$ 52 \\
\$ 126 \\
\$ 327\end{array}$ & $\begin{array}{l}\$ 56 \\
\$ 52 \\
\$ 126 \\
\$ 327\end{array}$ & $\begin{array}{l}\mathbf{0} \\
\mathbf{0} \\
\mathbf{0} \\
\mathbf{0}\end{array}$ & $\begin{array}{l}\mathbf{0} \\
\mathbf{0} \\
\mathbf{0} \\
\mathbf{0}\end{array}$ \\
\hline Seasonal & $\begin{array}{l}\text { Caulk cracks } \\
\text { Weatherstrip doors and windows } \\
\text { Replace broken windows/storm goors } \\
\text { Clean and tune up the furnace }\end{array}$ & $\begin{array}{r}\$ 39 \\
\$ 39 \\
\$ 5 \\
\$ 12 \\
\end{array}$ & $\begin{array}{rr}\$ & 19 \\
\$ & 40 \\
\$ & 3 \\
\$ & 0 \\
\end{array}$ & $\begin{array}{rr}\$ & 54 \\
\$ & 40 \\
\$ & 5 \\
\$ & 50 \\
\end{array}$ & $\begin{array}{l}\$ 271 \\
\$ 250 \\
\$ 34 \\
\$ 60 \\
\end{array}$ & $\begin{array}{c}\$ 217 \\
\$ 210 \\
\$ 29 \\
(\$ 190)\end{array}$ & $\begin{array}{l}0.5 \\
1.0 \\
0.6 \\
0\end{array}$ & $\begin{array}{l}1.9 \\
2.1 \\
1.6 \\
\text { never }\end{array}$ \\
\hline One-Time & $\begin{array}{l}\text { Install clock thermostat } \\
\text { Install more efficlent furnace } \\
\text { Turn down water heater thermostat } \\
\text { Install water flow restrictor } \\
\text { Insulate hot water pipes } \\
\text { Insulate hot water heater } \\
\text { Insulate the attic } \\
\text { Insulate the crawl space } \\
\text { Insulate in the walls } \\
\text { Install f1replace doors/caps }\end{array}$ & $\begin{array}{l}\$ 30 \\
\$ 81 \\
\$ 8 \\
\$ 11 \\
\$ 2 \\
\$ 3 \\
\$ 16 \\
\$ 18 \\
\$ 89 \\
\$ 8\end{array}$ & $\begin{array}{rr}\$ 40 \\
\$ 700 \\
\$ & 0 \\
\$ 10 \\
\$ 2 \\
\$ 10 \\
\$ 150 \\
\$ 60 \\
\$ 260 \\
\$ 100\end{array}$ & $\begin{array}{rr}\$ & 40 \\
\$ & 700 \\
\$ & 0 \\
\$ & 10 \\
\$ & 0 \\
\$ & 10 \\
\$ & 300 \\
\$ & 60 \\
\$ 1460 \\
\$ 100\end{array}$ & $\begin{aligned} \$ 183 \\
(\$ 97) \\
\$ 56 \\
\$ 72 \\
\$ 13 \\
\$ 12 \\
(\$ 31) \\
\$ 74 \\
\$ 402 \\
(\$ 44)\end{aligned}$ & $\begin{array}{c}\$ 143 \\
(\$ 797) \\
\$ 56 \\
\$ 62 \\
\$ 13 \\
\$ 2 \\
(\$ 331) \\
\$ 14 \\
(\$ 1058) \\
(\$ 144)\end{array}$ & $\begin{array}{l}1.3 \\
8.6 \\
0 \\
1.1 \\
1.0 \\
3.3 \\
9.4 \\
3.3 \\
2.9 \\
12.5\end{array}$ & $\begin{array}{r}2.7 \\
17.2 \\
0 \\
1.8 \\
1.0 \\
6.7 \\
28.1 \\
6.7 \\
19.3 \\
25.0\end{array}$ \\
\hline
\end{tabular}

assumes a 20 percent per year increase in energy costs beyond inflation. Then the "Do-It-Yourseif" column under "Net 5-Year Savings" 18 the First-Year Savings compunded for four additional years at 20 percent per year minus the "Cost of Materials." The "Contracted Out" colum 18 simllar but the "Cost of Labor" Is subtracted as well as "Cost of Mater1als."

"Payback Period" for "Do-It-Yourse1f" homeowners 18 "First-Year Savinge" divided by "Cost of Materlals"; for "Contracted Out" homeowners, it 1s "First-Year Savings" divided by "Cost of Materials" plus "Cost of Labor."

Assumes action 18 done once and 1 t lasts for five years.

do achieve an energy saving from cleaning and tuning up a furnace, some experts say this activity must be done annugl1y. "Net 5-Year Saving" shown are 5 times the net first year savings. These compound as well.

'Savings are In addition to those acheived by just manually turning down the thermostat at all times to no higher than $65^{\circ} \mathrm{F}$. Dual setback thermostats allow temperatures to be automatically turned back both during the day (when away for work) and at
night. 
different kinds of energy-saving behaviors (continuous, seasonal, and one-time actions), the marketing task for public policy here is to tailor informational communications to specific segments.

Marketing Actions for Public Policmakers

- It is apparent from Table 3 that distinctly different household behaviors are sought in order to achieve energy savings from each of the three categories of energy-saving actions. These behaviors are:

Continuous - Do these no-cost actions yourself daily without outside help

Seasonal - Do these low-cost actions at the start of the high-energy season by yourself or using a contractor

One-Time - Get an energy audit and do the recommended cost-effective energy actions yourself or using a contractor

Distinctly different marketing strategies are needed to achieve these behaviors. Table 4 relates (1) the household behaviors sought by public policy and ways to overcome the barriers to action present at each stage of household's decision process to (2) the three categories of energy-saving actions. The household behaviors sought vary significantly by effort and cost involved, frequency, timing during the year, and need for outside assistance. So the ways to overcome barriers to action vary significantly, as shown in Table 4 .

For example, energy savings from continuous actions must be "rewon" daily. No outside help from a contractor is needed by a household to" acheive these savings. So the goal of public policy is to motivate households to take these actions daily during the high energy-use season (winter in the North, summer in the South) by informing them of potential savings ("reducing your winter thermostat setting one degree will lower your heating bill by three percent"). 
TABLE 4

HOUSEHOLD BEHAVIORS SOUGHT BY PUBLIC POLICYMAKERS AND WAYS OF OVERCOMING BARRIERS TO ACTION, BY CATEGORY OF ENERGY-SAVING ACTION

\begin{tabular}{|c|c|c|c|c|}
\hline \multirow{2}{*}{$\begin{array}{l}\text { Behavior Sought } \\
\text { or How to } \\
\text { Overcome Barrier }\end{array}$} & \multirow{2}{*}{ Specific Characteristic } & \multicolumn{3}{|c|}{ Category of Energy-Saving Action } \\
\hline & & Continuous & Seasonal & One-TIme \\
\hline \multirow{4}{*}{$\begin{array}{l}\text { Nature of } \\
\text { Household } \\
\text { Action or } \\
\text { Behavior } \\
\text { Sought by } \\
\text { Public Policy }\end{array}$} & Behavior sought & $\begin{array}{l}\text { "Do-these-yourself without } \\
\text { outside help" } \\
\end{array}$ & $\begin{array}{l}\text { "Do these low-cost actions by } \\
\text { yourse1f or using a contractor" }\end{array}$ & $\begin{array}{l}\text { "Get an energy audit and the cost- } \\
\text { effective actions do yoursèlf or } \\
\text { using contractor" }\end{array}$ \\
\hline & Frequency of behavior & $\begin{array}{l}\text { Dally, during high energy-use } \\
\text { season }\end{array}$ & $\begin{array}{l}\text { Annual1y, before high energy-use } \\
\text { season }\end{array}$ & Once, for each action \\
\hline & $\begin{array}{l}\text { Time and cost Involved } \\
\text { for household }\end{array}$ & Takes time but no cost & Takes time and low cost & $\begin{array}{l}\text { Takes time and significant } \\
\text { cost }\end{array}$ \\
\hline & $\begin{array}{l}\text { Need for outside help in } \\
\text { taking behavior }\end{array}$ & None & $\begin{array}{l}\text { None for do-it-yourselfer; } \\
\text { contractor for others }\end{array}$ & $\begin{array}{l}\text { Energy auditor and contractor } \\
\text { for nearly all }\end{array}$ \\
\hline \multirow{4}{*}{$\begin{array}{l}\text { Ways to } \\
\text { overcome } \\
\text { Barriers to } \\
\text { a Household's } \\
\text { Taking Energy } \\
\text { Actions }\end{array}$} & $\begin{array}{l}\text { Stage 1: Awareness (Barrier: } \\
\text { Household doesn't know an } \\
\text { energy problem exists) }\end{array}$ & $\begin{array}{l}\text { Public information on typical } \\
\text { total annual savings possible } \\
\text { from taking continuous act lons }\end{array}$ & $\begin{array}{l}\text { Publish information on typical } \\
\text { total annual savings possible } \\
\text { from taking seasonal actions }\end{array}$ & $\begin{array}{l}\text { Publish information on typical } \\
\text { total annual savings possible from } \\
\text { taking one-time actions }\end{array}$ \\
\hline & $\begin{array}{l}\text { Stage 2: Choice (Barrier: } \\
\text { Household doesn't know } \\
\text { costs and savings of } \\
\text { energy-saving actions }\end{array}$ & $\begin{array}{l}\text { Publish Information on typical } \\
\text { energy savings avallable from } \\
\text { spectfic actions; neighborhood } \\
\text { workshops }\end{array}$ & $\begin{array}{l}\text { Publish information on typical } \\
\text { energy savings and costs for } \\
\text { spectfic act Ions; neighborhood } \\
\text { workshops }\end{array}$ & $\begin{array}{l}\text { Publish Information on typical } \\
\text { energy savings and costs for } \\
\text { specific actions and how to get } \\
\text { an energy audit }\end{array}$ \\
\hline & $\begin{array}{l}\text { Stage 3: Implementation } \\
\text { (Barrier: Household can't } \\
\text { perform action or find } \\
\text { ef fective contractor, } \\
\text { energy auditor, or } \\
\text { fInancing) }\end{array}$ & $\begin{array}{l}\text { Motivate households continually } \\
\text { to take these actions dafly }\end{array}$ & $\begin{array}{l}\text { Educate do-it-yourselfers on how } \\
\text { to take the action and others on } \\
\text { identifying effective } \\
\text { contractor }\end{array}$ & $\begin{array}{l}\text { Stimulate all households to get } \\
\text { an energy audit and provide } \\
\text { assistance in finding ef fective } \\
\text { contractor and financing }\end{array}$ \\
\hline & $\begin{array}{l}\text { Stage 4: Use and Evaluation } \\
\text { (Barrier: Household can't } \\
\text { evaluate energy savings } \\
\text { from actions) }\end{array}$ & $\begin{array}{l}\text { None immediately; possibly } \\
\text { install energy meters to provide } \\
\text { incentive for continuous beha- } \\
\text { viors; gain word--of-mouth support }\end{array}$ & $\begin{array}{l}\text { None Immediately; possibly Instali } \\
\text { energy meters to provide Incentive } \\
\text { for seasonal behaviors; gain word- } \\
\text { of-mouth support }\end{array}$ & $\begin{array}{l}\text { No feedback on energy savings } \\
\text { necessary; savings from one- } \\
\text { time behaviors are usually } \\
\text { permanent }\end{array}$ \\
\hline
\end{tabular}


In contrast, many one-time actions require outside assistance because of their complexity. So households should be stimulated to get energy audits to assess their unique needs for the one-time actions that have longer payback periods. They can then do those for which they believe the benefits outweigh the costs.

The bottom row of Table 4 suggests the importance of acheiving local wordof-mouth support to gain energy savings from continuous and seasonal actions. Some cities have accomplished this through nonprofit neighborhood "energy companies" that hold workshops where homeowners share ideas for energy actions and get assistance with information on potential cost savings of various actions, how to do them, and how to get energy audits and low-interest loans.

Table 5 relates specific marketing strategies -- in terms of product, price, distribution, and communications -- that local governments and energy utilities can use to the three categories of energy-saving actions. Again, the strategies differ significantly because the behaviors sought do. Table 5 even implies a three-step foot-in-the-door strategy to try to trade up homeowners' behaviors from continuous to seasonal to one-time actions. This means moving them from nocost, immediate payback actions to higher cost, longer payback actions -- while stimulating them to continue doing the initial no-cost, low-cost actions.

The communications strategy shown in the bottom of Table 5 illustrates how public policy strategies vary with continuous, seasonal, and one-time actions. For example, in terms of frequency and timing of messages, energy-saving behaviors should be acheived for continuous actions by frequent messages during the high-energy season while seasonal actions should be sought one or two months earlier. And savings from one-time actions must.be sought at particular times during the year -- clock thermostats during the high-energy season and insulation during the off-season. McDougall (1980) has cited effective appeals to use, such 
TABLE 5

MARKETING STRATEGIES FOR PUBLIC POLICYMAKERS TO USE, BY GATEGORY OF ENERGY-SAVING ACTION

\begin{tabular}{|c|c|c|c|c|}
\hline \multirow{2}{*}{\multicolumn{2}{|c|}{ Marketing Strategy }} & \multicolumn{3}{|c|}{ Category of Energy-Saving Action } \\
\hline & & Continuous & Seasonal & One-TIme \\
\hline \multicolumn{2}{|c|}{ Product Strategy } & $\begin{array}{l}\text { None, because no new products } \\
\text { are needed }\end{array}$ & $\begin{array}{l}\text { Make low-cost maintenance } \\
\text { materials usable and accessible }\end{array}$ & $\begin{array}{l}\text { Make new technology products } \\
\text { (like clock thermostats, Improved } \\
\text { insulation) available }\end{array}$ \\
\hline \multicolumn{2}{|c|}{ Price Strategy } & $\begin{array}{l}\text { None, because no purchase is } \\
\text { required }\end{array}$ & $\begin{array}{l}\text { Market prices for maintenance } \\
\text { matertals }\end{array}$ & $\begin{array}{l}\text { Market prices with tax credits for } \\
\text { actions; low-1nterest loans for } \\
\text { low-1ncome households }\end{array}$ \\
\hline \multicolumn{2}{|c|}{ Distribution Strategy } & $\begin{array}{l}\text { None, for no products are } \\
\text { required }\end{array}$ & $\begin{array}{l}\text { Distribute maintenance products } \\
\text { through hardware stores or "mobile" } \\
\text { store on wheels" In neighborhood }\end{array}$ & $\begin{array}{l}\text { Distribute products through } \\
\text { standard outlets }\end{array}$ \\
\hline \multirow[t]{4}{*}{$\begin{array}{l}\text { Communications } \\
\text { Strategy }\end{array}$} & Appeals & $\begin{array}{l}\text { "Maintain your present energy } \\
\text { lifestyle at no extra cost" }\end{array}$ & $\begin{array}{l}\text { "Maintain your present energy life- } \\
\text { style with low-cost home maintenance } \\
\text { actions" }\end{array}$ & $\begin{array}{l}\text { "Maintain your present energy lifestyle } \\
\text { with careful investment in major energy- } \\
\text { saving actions" }\end{array}$ \\
\hline & $\begin{array}{l}\text { Information in } \\
\text { message }\end{array}$ & Savings Information & $\begin{array}{l}\text { Trade-off information on savings } \\
\text { and costs; how to find qualified } \\
\text { contractors }\end{array}$ & $\begin{array}{l}\text { Trade-off Information on savings and } \\
\text { costs; how to find a qualified energy } \\
\text { auditor, contractor, lender }\end{array}$ \\
\hline & Media & $\begin{array}{l}\text { Newspapers, inserts in utflity } \\
\text { b1lls; neighborhood groups to gain word- } \\
\text { of-mouth support }\end{array}$ & $\begin{array}{l}\text { Newspapers, Inserts in utilfty bills, } \\
\text { hardware stores, neighborhood groups } \\
\text { to gain word-of-mouth support }\end{array}$ & $\begin{array}{l}\text { Newspapers, utflities, neighborhood } \\
\text { service groups, banks, thrift institu- } \\
\text { tions }\end{array}$ \\
\hline & $\begin{array}{l}\text { Frequency and } \\
\text { timing of message }\end{array}$ & $\begin{array}{l}\text { often, throughout high-energy } \\
\text { season }\end{array}$ & $\begin{array}{l}\text { Often, one or two months prior to } \\
\text { high-energy season }\end{array}$ & $\begin{array}{l}\text { Selective, relative to action and } \\
\text { high-energy seasonb }\end{array}$ \\
\hline
\end{tabular}

assumes economical "energy meter" for quick feedback on energy use will not be avallable in near future.

${ }^{b}$ For example, pronote clock thermostats during high-energy season, insulation in of f-season. 
as cost savings, maintenance of life style with minimum inconvenience, and energy-saving actions with high benefit-cost ratios. Table 5 shows how these appeals vary with the kind of energy-saving action needed.

\section{Conclusions and Future Research Directions}

Energy-saving decisions by consumers and public policies to conserve energy are clearly not the independent issues they have often appeared to be in past research. Instead, they must be linked more closely in the future. At the consumer level, homeowners must be given more easily understandable information at each stage of their energy decisions -- from more precise information on the dollar costs and savings of alternative energy actions (at the awareness and choice stages) to names of approved energy-auditors, contractors, and lenders (at the implementation and use-evaluation stages). At the public policy level, marketing strategies must be directed at the combination of actions and consumer segments where households will benefit most and where the greatest aggregate energy savings will occur. Sometimes these goals conflict. For example, lowincome households may be assisted in taking costly, one-time actions with special tax or loan incentives.

Research on feedback, prompts, monetary incentives, and public commendation notwithstanding, limited public budgets dictate that publicly-provided information is the only game in town for most public-policy actions for the foreseeable future. But that information must be made more accessible, understandable, and operational to consumers. Because of regional differences in energy use, local governments and energy utilities are the most effective sources of the information. These two groups should collaborate on marketing strategies. to communicate useful energy-conservation information to homeowners. 
Future research effort should focus on improving energy trade-off information to include: more energy-saving actions, more precise estimates of the costs and savings of each, the best way of describing benefit-cost relations (first-year savings, net five-year savings, payback, return on investment), and ways to improve consumer understanding of these energy trade-offs. Research should also assess whether households are more likely to change their energy behaviors by moving them through a three-step sequence from continuous to seasonal to one-time actions. Ultimately, the goal is to stimulate homeowners to make their own energy trade-offs, to take the simple continuous and seasonal actions by themselves to save energy, and to get help with the more complex onetime actions.

Through this research, individual decisions can be made to match the longterm public good more closely. Then public policymakers can direct energyconservation information and programs at household actions using marketing strategies that will give the most collective national energy savings from a limited budget. 


\section{REFERENCES}

Allen, Chris T., Roger J. Calantone, and Charles D. Schewe (1982), 'Consumers' Attitudes about Energy Conservation in Sweden, Canada, and the United States, with Implications for Policymakers," Journal of Marketing and Public Policy, 1, 57-67.

Anderson, C. Dennis and Gordon H. G. McDougall (1980), Conservation Energy Research: An Annotated Bibliography, Behavioral Energy Research Group, University of British Columbia.

Beales, Howard, Michael B. Mazis, Steven C. Salop, and Richard-Staelin (1981), "Consumer Search and Public Policy," Journal of Consumer Research, 8 (June), 11-22.

Becker, Lawrence J. (1978), "Joint Effect of Feedback and Goal Setting on Performance: A Field Study of Residential Energy

Conservation," Journal of Applied Psychology, Vol. 63, No. 4, 428433.

Berry, Linda, Jon Soderstrom, Eric Hirst, Bobbie Newman, and Rose Weaver (1981), Review of Evaluations of Utility Home Energy Audit Programs, Oak Ridge National Laboratory.

Bloom, Paul N. and William D. Novelli (1981), "Problems and Challenges In Social Marketing," Journal of Marketing, 45 (Spring), 36-47.

Booz-Allen and Hamilton (1980), Electric and Gas Utility Marketing of Residential Energy Conservation, U.S. Department of Energy, Washington, D.C.

Cannon, Lisa (1980), "Energy Conservation in the United States: Federal Programs Versus Individual Community Actions," Banff: International Conference on Consumer Behavior and Energy Use.

Craig, C. Samuel and John M. McCann (1978a), "Assessing Communication Effects on Energy Conservation," Journal of Consumer Research, 5 (September), 82-88.

(1978b), "The Impact of Persuasive Communications on Energy Conservation," Energy Systems and Policy, $2,433-447$.

Cunningham, William H. and Sally Cook Lopreato (1977), Energy Use and Conservation Incentives: A Study of the Southwestern United States, New York: Praeger Publishers.

Cunningham, William H. and Joseph Brondel (1978), "Energy Conservation, Price Incentives, and Payback Periods," in Advances in Consumer Research, Vol. V, H. Keith Hunt, ed., Ann Arbor, Michigan: Association for Consumer Research.

Department of Energy (1979a), ACT/ONE Activate Communities Today/ Organize Now for Energy, Office of Consumer Affairs (March), Washington, D.C. 
Department of Energy (1979b), Local Government Energy Activities: Volume 2: Detailed Analysis of Twelve Cities and Counties (July), Washington, D.C.

Deutscher, Terry and Hugh Munro (1980), The Role of Home Energy Audits in Facilitating Residential Retrofits, Ottawa: Consumer Service, Consumer and Corporate Affairs Canada.

Evans, John L., J. R. Brent Ritchie, and Gordon H. G. McDougall (1978/1979), "Energy Use and Consumer Behavior: A Framework for Analysis and Policy Formulation," Journal of Business Administration, 1 and 2 (Fall/Spring), 165-181.

Farhar, Barbara C., Patricia Weis, Charles T. Unseld, and Barbara A. Burns (1979), Public Opinion About Energy: A Literature Review, U.S. Department of Commerce, Washington, D.C.

Frieden, Bernard J. (1981), "Household Energy Consumption: The Record and the Prospect," unpublished report of the Program on Neighborhood and Regional Change, Massachusetts Institute of Technology.

Gaskel1, George, P. Ellis, and R. Pike (1980), "Promoting Efficiency and Conservation through Consumption Feedback and Information," Banff: International Conference on Consumer Behavior and Energy Use.

Geller, E. Scott (1982), "The Energy Crisis and Behavioral Science: A Conceptual Framework for Large Scale Intervention," in A. W. Childs and G. B. Melton (Eds.), Rural Psychology, New York: Plenum Press.

Hardin, Garrett (1968), "The Tragedy of the Commons," Science, 162 (December 13), 1243-1248.

Hanna, Sherman (1978), "Evaluation of Energy Saving Investments," Journal of Consumer Affairs, 12 (Summer), 63-75.

Hayes, Steven C. and John D. Cone (1977), "Reducing Residential Electrical Energy Use: Payment, Information, and Feedback," Journal of Applied Behavior Analysis, 10 (Fal1), 425-435.

Heslop, Louise A., Loris Moran, and Ami Cousineau (1981), "'Consciousness' in Energy Conservation Behavior: An Exploratory Study," Journal of Consumer Research, 8 (December), 299-305.

Hirst, Eric and Peter Lazare (1980), "Evaluation of a Computerized Home Energy Audit in Minnesota," Banff: International Conference on Consumer Behavior and Energy Use.

Hutton, R. Bruce, and Dennis L. McNeill (1981a), "A Market-Planning Approach to the Analysis of Consumer Information for Decisionmaking," unpublished report to the U.S. Department of Energy, College of Business Administration, University of Denver. 
, and (1981b), "The Value of Incentives in

Stimulating Energy Conservation," Journal of Consumer Research, 8

(December) 291-298.

Johnston, Wesley J., Martha C. Cooper, and Thomas J. Page, Jr. (1981).

"Consumer Energy Usage and the Tragedy of the Commons Phenomenon," unpublished working paper, College of Administrative Science, The Ohio State University.

Kohlenberg, Robert, Thomas Phillips, and W. Proctor (1976), "A Behavioral Analysis of Peaking in Residential Electrical Energy Consumption," Journal of Applied Behavioral Analysis, Vo1. 9, 1318 .

McDouga11, Gordon H. G., John D. Claxton, J. R. Brent Ritchie, and C. Dennis Anderson (1981), "Consumer Energy Research: A Review," Journal of Consumer Research, 8 (December), 343-354.

(1980), "Alternative Energy Conservation Appeals: Relative Effects," in the American Marketing Association Proceedings, Vol. 46, Richard P. Bagozzi, et al., eds., Chicago: American Marketing Association, 432-435.

, and J. R. Brent Ritchie (1979), "Consumer Energy

Conservation: A Framework for Policy Research," in Advances in Consumer Research, Vol. VI, Jerry C. Olson, ed., San Francisco: Association of Consumer Research.

Milstein, Jeffrey S. (1977), "Attitudes, Knowledge, and Behavior of American Consumers Regarding Energy Conservation with Some Implications for Governmental Action," in Advances in Consumer Research, Vol. IV, William D. Perrault, Jr., ed., Association for Consumer Research, 315-321.

Richman, Al (1979), "The Polls: Public Attitude Toward the Energy Crisis," Public Opinion Quarterly, Vol. 43, 576-585.

Ritchie, J. R. Brent, Gordon H. G. McDougall, and John D. Claxton (1981), "Complexities of Household Energy Consumption and Conservation," Journal of Consumer Research, 8 (December), 233242 .

Rothchild, Michael L (1979), "Marketing Communications In Nonbusiness Situations or Why Its So Hard to Sell Brotherhood Like Soap," Journal of Marketing, 43 (Spring), 11-20.

Rudelius, William and Richard Weijo (1980), Energy Conservation for Homeowners: An Action Program for the City of Saint Paul, University of Minnesota: College of Business Administration and the Center for Urban and Regional Affairs. 
Russo, J. E. (1977), "A Proposal to Increase Energy Conservation Through Provision of Consumption and Cost Information to Consumers," in the American Marketing Association Proceedings, Vol. 43, Barnett A. Greenberg and Danny N. Bellenger, eds., Chicago: American Marketing Association, 437-442.

Stern, Paul C. (1976), "Effect of Incentives and Education on Resource Conservation Decisions in a Simulated Commons Dilemma," Journal of Personality and Social Psychology, 34, 1285-1292.

, and Gerald T. Gardner (1981), "Psychological Research and Energy Policy," American Psychologist, Vol. 36, No. 4 (April), 329-342.

Stobaugh, Robert. and Daniel Yergin (1979), Energy Future: Report of the Energy Project at the Harvard Business School, New York: Random House.

Verhallen, Theo M. M. and W. Fred van Roaij (1980), "Household Behavior and the Use of Natural Gas for Home Heating," Journal of Consumer Research, 8 (December), 253-257.

Walker, Bruce J. and Kenneth A. Coney (1981), "Cosumer Adoption of an Energy Conservation Project," in the American Marketing Association Proceedings, Vol. 47, Kenneth Bernhardt, et al., eds., Chicago: American Marketing Association, 245-248.

Weijo, Richard, and Steven W. Hartley (1982), "Validating Stages in the Energy Conservation Decision Process Using a Unidimensional Unfolding Model," in SWAIDS Conference Proceedings, Vo1. 8, Dallas: Southwest American Institute for Decision Sciences.

Winett, Richard A., John H. Kagel, Raymond C. Battalio, and Robin C. Winkler (1978), "Effects of Monetary Rebates and Daily Feedback and Information on Residential Electricity Conservation," Journal of Applied Psychology, Vol. 63, (January), 73-80. 